6. Informatsiia derzhavnoi sluzhby Ukrainy z pytan pratsi URL: http://dsp.gov.ua/statystychni-dani-vyrobnychoho-travma-2/. (Data zvernennia 02.02.2020)

Fondu

sotsialnoho

strakhuvannia

Ukrainy

URL:

7.

8. Cherneha R. Derzhavna sluzhba Ukrainy z pytan pratsi: zavdannia, perspektyvy, dosiahnennia. Materialy III mizhnarodnoi naukovopraktychnoi konferentsii «Promyslova bezpeka: naikrashchi praktyky-2015». Lviv. (6-8 zhovtnia). s.12.

9. Ofitsiinyi sait MOP URL: https://www.ilo.org/dyn/normlex/en/f?p=1000:11200:0: (Data zvernennia 10.02.2020)

10. Santush A. Uzghodzhennia ukrainskoho zakonodavstva z yevropeiskoiu normatyvno-pravovoiu bazoiu z bezpeky i hihiieny pratsi: kliuchovi pytannia URL: http://oppb.com.ua/articles/uzgodzhennya-ukrayinskogo-zakonodavstva-z-yevropeyskoyu-normatyvno-pravovoyubazoyu-z-0. (Data zvernennia 20.02.2020)

11. Dudin V. Chy startuie u 2019 r. Reforma okhorony pratsi i yaka same? URL: https://rev.org.ua/chi-startuye-u-2019-r-reforma-oxoronipraci-i-yaka-same/. (Data zvernennia 20.02.2020)

12. Dudin V. Derehuliatsiia chy depopuliatsiia? 10 pytan pro kontrol URL: https://rev.org.ua/deregulation-or-depopulation-2/. (Data zvernennia 01.03.2020

13. Vysnovok Komitetu Verkhovnoi Rady Ukrainy z pytan intehratsii Ukrainy z YeS shchodo proektu Zakonu «Pro pratsiu» URL: http://w1.c1.rada.gov.ua/pls/zweb2/webproc4_1?pf3511=67833. (Data zvernennia 01.03.2020)

14. Reformuvannia trudovoho zakonodavstva: rezoliutsiia kruhloho stolu URL: https://hrliga.com/index.php? module=news\&op=view\&id=21384. (Data zvernennia 05.03.2020)

15. Ermolenko A. Ynspektorы po okhrane truda poluchat sverkhpolnomochyia y budut po-novomu shtrafovat byznes URL: https://ubr.ua/labor-market/ukrainian-labor-market/inspektory-po-okhrane-truda-poluchat-sverkhpolnomochija-i-budut-po-novomu-

shtrafovat-biznes-. (Data zvernennia 05.03.2020)

Дата подання публікації 18.03.2020 p.

УДК 338.48-6.615.8

Матвійчук Л.Ю, д.е.н., професор, Matviichuk L. Doctor of Economic Sciences, Professor http://orcid.org/0000-0003-1694-6178

Чепурда Л.М., д.е.н., професор

Chepurda L. Doctor of Economic Sciences, Professor http://orcid.org/0000-0002-8941-9427

\title{
ФОРМУВАННЯ ДОСТУПНОГО СЕРЕДОВИЩА ІНКЛЮЗИВНОГО ТУРИЗМУ
}

\author{
Луиьький національний технічний університет \\ Черкаський державний технологічний університет
}

Інклюзивний туризм достатньо новий напрямок дослідження, у порівнянні з рекреаційним чи пізнавальним туризмом. Проте, трактування та значення понять, які визначають зміст дефініції «інклюзивний туризм», $є$ предметом наукових дискусій. Аналіз світового досвіду засвідчив, що туристи 3 особливими потребами займають важливий сегмент туристичного ринку. Інклюзивний туризм $\epsilon$ необхідним видом туризму у кожному туристичному регіоні різних рівнів. Це один 3 найбільш інтенсивно розвиваючих видів туризму.

Детального аналізу потребує визначення змісту інклюзивного туризму, теоретичних та прикладних аспектів формування доступного середовища зазначеного виду туризму зважаючи на його специфіку.

В статті проаналізовані підходи вчених до трактування поняття «інклюзивний туризм», визначено ключові критерії змістовного наповнення досліджуваного виду туризму (адаптивність, комунікативність, доступність, відповідність, безпека, інфраструктура та раціональність). Проведено аналіз змісту та значення доступного середовища інклюзивного туризму, доведено доцільність його формування, визначено ключові компоненти такого середовища (інституційні, просторові, інформаційні, комунікативно-організаційні). Доведено, що в інклюзивному туризмі, ключову роль відіграють туристичні суб'єкти - туристи, для якого надаються туристичні послуги та фахівці - які надають зазначені туристичні послуги або продають туристичні продукти. Визначено власне бачення поняття «інклюзивний туризм» як специфічний (безпечний) вид туризму, основною метою якого є безбар'єрний доступ до усіх туристичних ресурсів, позитивний психологічний клімат, рівність можливостей усіх туристів, повномасштабне інформування людей з особливими потребами про можливості того чи іншого туристичного об'єкту, а також передбачає швидку здатність суб'єктів туризму перелаштовуватись відповідно до запитів людей з особливими потребами.

Ключові слова: інклюзія, доступне середовище, туризм для всіх, безпека. 


\title{
FORMATION OF AN ACCESSIBLE ENVIRONMENT OF INCLUSIVE TOURISM
}

\author{
Lutsk National Technical University \\ Cherkasy State Technological University
}

Inclusive tourism is a fairly new area of research compared to recreational or cognitive tourism. However, the interpretation and meaning of the concepts that define the meaning of the term «Inclusive Tourism» are the subject of scientific debate. The analysis of world experience has shown that tourists with special needs occupy an important segment of the tourist market. Inclusive tourism is a necessary type of tourism in each tourist region at different levels. It is one of the most intensively developing types of tourism.

Detailed analysis requires a clear definition of the content of inclusive tourism and the definition of theoretical and applied aspects of the formation of accessible environment of this type of tourism, taking into account its specificity.

The article analyzes the approaches of scientists to the interpretation of the concept of «inclusive tourism», identifies the key criteria for meaningful content of the studied type of tourism (adaptability, communicativeness, accessibility, conformity, security, infrastructure and rationality). The analysis of the content and significance of the accessible environment of inclusive tourism is carried out, the expediency of its formation is proved, the key components of such environment are defined (institutional, spatial, informational, communicative-organizational). It has been proved that in inclusive tourism, the key role is played by tourist entities - tourists for whom tourist services are provided and professionals - who provide these tourist services or sell tourist products. Our own vision of the concept of «inclusive tourism» as a specific type of tourism, the main purpose of which is barrier-free access to all tourist resources, positive psychological climate, equal opportunities for all tourists, full-scale informing people with special needs about the possibilities of a tourist object, and also provides for the rapid ability of tourism entities to adapt to the needs of people with special needs.

Keywords: inclusion, accessible environment, tourism for all, security.

Постановка проблеми у загальному вигляді i iї зв'язок 3 важливими науковими та практичними завданнями. Важливість формування доступного середовища в туризмі загалом та інклюзивному туризмі зокрема, $\epsilon$ надзвичайно важливим в сучасному світі. Щороку значення туризму в економіці більшості регіонів світу зростає, зростає також кількість туристів з особливими потребами. У світі більше $15 \%$ населення людей з особливими потребами і їх кількість постійно зростає. Крім того, події пов'язані з поширенням пандемії світового масштабу COVID-19 потребують перегляду критеріїв формування доступного середовища саме в туристичній галузі загалом та в інклюзивному туризмі зокрема.

Аналіз останніх досліджень, у яких започатковано вирішення проблеми. Питання інклюзивного туризму в Україні розглянуто недостатньо у зв'язку з тим, що це порівняно новий напрям в туризмі. Широке коло питань проблематики розвитку інклюзивного туризму присвячені наукові праці дослідників: Анікеєвої О. А., Бейдика О. О., І Іванової В. М., Кирпич І. О., К Ковальської Л. В., Маньшиної Н. І., Медведського Р. С., Перфільєвої М. В., Смірнової Д. Б., С Сородинової Ю. С., Угоднікової О. І., Хрущ Ю. М. та інших. Проте, незважаючи на значні теоретичні та практичні дослідження інклюзивного туризму, авторами не запропоновано комплексного підходу до формування доступного середовища такого туризму та не визначено чітких критеріїв доступності.

Цілі статті. Основною метою дослідження є аналіз стану розвитку інклюзивного туризму в Україні, пошук шляхів його розвитку, визначення компонентів забезпечення доступності та комфортності для людей з особливими потребами, а також критеріїв доступності досліджуваного туризму.

Виклад основного матеріалу дослідження 3 повним обгрунтуванням отриманих наукових результатів. У сучасних умовах середовище туристичної галузі загалом формується не дуже ефективно. В цьому випадку, безпека та доступність, під впливом різних факторів не в повній мірі відповідає запланованому результату, 
зменшується попит на пропоновані туристичні послуги, погіршуються показники діяльності туристичних підприємства. Зазначене, може призвести до погіршення іміджу туристичних об’єктів та територій. Щоб запобігти цьому, потрібно ефективно та продумано формувати доступне туристичне середовище, згідно діючих світових норм та стандартів. Для кожного типу туристичного об'єкту та туристичного регіону середовище має свою специфіку, проте доцільно дослідити та визначити загальні аспекти формування такого середовища.

В туризмі загалом, та інклюзивному туризмі зокрема, ключову позицію займають туристичні суб’єкти: 3 одного боку - туристи, для якого надаються туристичні послуги, з іншого боку - фахівці, які надають відповідні туристичні послуги або продають туристичні продукти. У зв'язку з цим, вважаємо за доцільне, розглянути підходи вчених до трактування поняття «інклюзивний туризм».

Інклюзивний туризм як специфічний вид туристичної діяльності почав розвиватися відносно недавно. В науковій та практичній літературі окрім терміну «інклюзивний туризм» можна зустріти поняття «доступний», «універсальний», «безбар'єрний», «інклюзивно-реабілітаційно-соціальний туризм», «туризм для всіх», «пара туризм», «туризм для інвалідів», «соціальний», «реабілітаційний», «туризм для людей $з$ обмеженими можливостями» тощо. Для порівняння визначень «інклюзивний туризм» розглянемо таблицю 1.

Таблиця 1

Критеріальні підходи до трактування поняття «інклюзивний туризм»

\begin{tabular}{|c|c|c|}
\hline Джерело & Визначення & Критерій \\
\hline 1 & 2 & 3 \\
\hline $\begin{array}{c}\text { Всесвітня } \\
\text { туристська } \\
\text { організація } \\
{[9]}\end{array}$ & $\begin{array}{l}\text { Інклюзивний туризм - форма туризму, що включає в себе процес співпраці } \\
\text { між різними учасниками сфери туризму, який дає змогу людям з особливими } \\
\text { потребами в доступності, включаючи мобільну, візуальну, слухову і } \\
\text { когнітивну складові частини доступності, функціонувати незалежно, на рівних } \\
\text { умовах, із почуттям особистої гідності через надання універсальних } \\
\text { туристичних продуктів, послуг і середовища. }\end{array}$ & Комунікація \\
\hline $\begin{array}{l}\text { Н. Маньшина } \\
{[8]}\end{array}$ & $\begin{array}{l}\text { Інклюзивний туризм - процес розвитку туризму, який передбачає доступність } \\
\text { туризму для всіх, в плані пристосування інфраструктури туристичних центрів } \\
\text { і об'єктів туристського показу до різних потреб всіх людей, в тому числі } \\
\text { інвалідів, літніх, їх опікунів та членів сімей, людей } 3 \text { обмеженими } \\
\text { тимчасовими можливостями, сімей з маленькими дітьми. }\end{array}$ & Доступність \\
\hline $\begin{array}{l}\text { В. Лепський, Л. } \\
\text { Науменко, I. } \\
\text { Борисова } \\
\text { [5] }\end{array}$ & $\begin{array}{l}\text { Інклюзивно-реабілітаційно-соціальний туризм - це система заходів, } \\
\text { спрямованих на надання особам } 3 \text { інвалідністю можливості відновлення та } \\
\text { розвитку їх фізичного, соціального, духовного, творчого та інтелектуального } \\
\text { рівня з метою сприяння подальшої інтеграції в суспільство. }\end{array}$ & Сприйняття \\
\hline $\begin{array}{c}\text { Є. Ліханос, } \\
\text { О. Байдаков } \\
{[12]}\end{array}$ & $\begin{array}{l}\text { Доступний туризм - поняття, яке вказує на усунення/адаптацію саме фізичних } \\
\text { бар'єрів та асоціюється, насамперед, з фінансовою доступністю. }\end{array}$ & $\begin{array}{c}\text { Адаптація, } \\
\text { Економічніст } \\
\text { b }\end{array}$ \\
\hline $\begin{array}{l}\text { Д. Смірнова } \\
{[13]}\end{array}$ & $\begin{array}{l}\text { Безбар’єрний туризм - це переміщення осіб з постійною або тимчасовою } \\
\text { обмеженою здатністю до мобільного пересування та їх супроводжуючих на } \\
\text { територію, відмінну від постійного місця проживання, і маючу всі необхідні } \\
\text { ресурси для здійснення цілей подорожі }\end{array}$ & $\begin{array}{l}\text { Забезпе- } \\
\text { ченість } \\
\text { ресурсами }\end{array}$ \\
\hline $\begin{array}{l}\text { Д.Смірнова, } \\
\text { Ю.Смородина } \\
\quad[13]\end{array}$ & 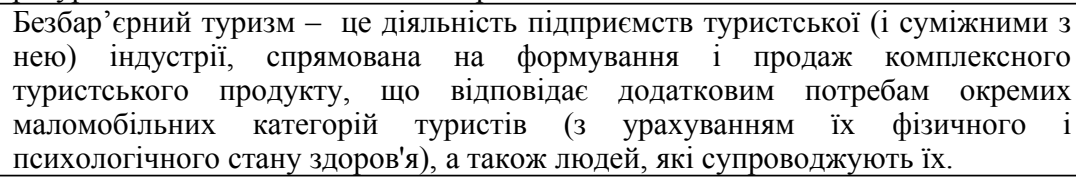 & Відповідність \\
\hline $\begin{array}{l}\text { Ю. Хрущ, } \\
\text { В. Іванова, } \\
\text { Р.Медведський } \\
{[15]}\end{array}$ & $\begin{array}{l}\text { Туризм для людей з інвалідністю - процес розвитку туризму, вид діяльності, } \\
\text { суб'єктом якого виступає особа } 3 \text { обмеженими можливостями здоров'я } \\
\text { (інвалід), спрямований на надання туристичного продукту, інформації, } \\
\text { окремих туристських послуг з урахуванням потреб інвалідів усіх нозологій, в } \\
\text { плані пристосування туристичної інфраструктури і об'єктів туристського } \\
\text { показу. }\end{array}$ & $\begin{array}{l}\text { Інфраструкту- } \\
\text { рність }\end{array}$ \\
\hline $\begin{array}{l}\text { Власне } \\
\text { бачення }\end{array}$ & $\begin{array}{l}\text { Інклюзивний туризм - це специфічний (безпечний) вид туризму, основною } \\
\text { метою якого є безбар'єрний доступ до усіх туристичних ресурсів, позитивний } \\
\text { психологічний клімат, рівність можливостей усіх туристів, повномасштабне } \\
\text { інформування людей з особливими потребами про можливості того чи іншого } \\
\text { туристичного об’єкту, а також передбачає швидку здатність суб'єктів туризму } \\
\text { перелаштовуватись відповідно до запитів людей з особливими потребами. }\end{array}$ & $\begin{array}{l}\text { Комплексний } \\
\text { підхід }\end{array}$ \\
\hline
\end{tabular}


Примітка: узагальнено на основі даних джерел [5, 8, 9, 12, 13, 15]

Аналіз наукової літератури з туризму засвідчив, що в Україні поки не існує загальноприйнятого визначення інклюзивного туризму, а існуючі підходи до його визначення не мають глибокого дослідження, яке розкривало б сутність цього явища.

Всесвітня туристська організація надає таке визначення інклюзивного туризму: «Інклюзивний туризм - це форма туризму, що включає в себе процес співпраці між різними учасниками сфери туризму, який дає змогу людям з особливими потребами в доступності, включаючи мобільну, візуальну, слухову і когнітивну складові частини доступності, функціонувати незалежно, на рівних умовах, із почуттям особистої гідності через надання універсальних туристичних продуктів, послуг і середовища» [9].

Більшість науковців трактують досліджуване поняття як туризм для інвалідів та осіб із відхиленнями у стані здоров'я, а також призначений для фізичної реабілітації, оздоровлення і соціальної інтеграції зазначеної категорії людей [14]. Проте, вважаємо за доцільне інклюзивний туризм розглядати як туризм для усіх категорій туристів 3 рівноправним доступом до усіх туристичних ресурсів.

Аналіз підходів вчених до змісту поняття «інклюзивний туризм» дозволив визначити основні критеріальні ознаки доступного середовища досліджуваного типу туризму:

- адаптивність - передбачає швидку здатність суб'єктів туризму перелаштовуватись відповідно до запитів людей з особливими потребами;

- комунікативність - передбачає повномасштабне інформування людей 3 особливими потребами про можливості того чи іншого туристичного об'єкту чи туристичного маршруту;

- доступність - пов'язана з безбар'єрним пересуванням та можливістю доступу до усіх туристичних об'єктів та користуванням усіма туристичними послугами.

- відповідність - включає позитивний психологічний клімат, рівність можливостей, поваги і гідного відношення людей один до одного;

- безпека - досягається дотриманням чітких технічних, санітарно-епідемічних, фізичних вимог, норм та правил згідно світових стандартів, а також усім типам туристів, в тому числі людям з особливими потребами, дозволяє отримати усю необхідну інформацію про туристичні об’єкти, їх категорії, зручності, заходи щодо безпеки;

- інфраструктурність - передбачає забезпеченість відповідними типами ресурсів туристичні об'єкти та території.

- раціональність, що включає пошук найоптимальніших шляхів використання туристичних ресурсів людей з особливими потребами.

Проаналізувавши підходи вчених до поняття «інклюзивний туризм», можна зробити висновок, що кожен із дослідників має власне бачення, щодо цього поняття. Тому на основі їхніх тлумачень вважаємо, що інклюзивний туризм - це специфічний вид туризму, основною метою якого є безбар'єрний доступ до усіх туристичних ресурсів, позитивний психологічний клімат, рівність можливостей усіх туристів, повномасштабне інформування людей з особливими потребами про можливості того чи іншого туристичного об'єкту, а також передбачає швидку здатність суб'єктів туризму перелаштовуватись відповідно до запитів людей з особливими потребами.

Наявність дієвої законодавчої бази щодо інклюзії, забезпечує рівне право на відпочинок усіх категорій туристів та відіграє важливу роль в розвитку туристичних регіонів. В Україні понятійний апарат у галузі інклюзивного туризму не закріплений в будь-яких нормативних документах. Закон України «Про туризм», який є основним нормативно-правовим документом, що здійснює регулювання у галузі туризму, не визначає поняття інклюзивного туризму. Проте у статті 6 Закону України «Про туризм» 
визначено, що державна політика у галузі туризму повинна здійснюватися на основі «забезпечення доступності туризму та екскурсійних відвідувань для дітей, молоді, людей похилого віку, осіб з інвалідністю та малозабезпечених громадян шляхом запровадження пільг стосовно цих категорій осіб» [3].

Вся туристична інфраструктура налаштована на обслуговування та задоволення потреб здорових людей. Незначна кількість туристичних фірм України декларує у своєму переліку послуги для людей з особливими потребами. Як правило, більшість готелей та садиб сільського зеленого туризму не пристосовані для забезпечення комфортних умов людей 3 особливими потребами. Більшість 3 низ не мають кваліфікованого персоналу та не знають як правильно обслуговувати таких гостей. Це потребує пошуку шляхів формування доступного середовища інклюзивного туризму [6].

Аналіз міжнародного досвіду 3 цього питання засвідчив багато дієвих інструментів формування такого середовища. Так, до структурних компонентів інклюзивного туризму міжнародними організаціями було включено наступні елементи [10]:

- забезпечення реалізації концепцій безбар'єрної архітектури шляхом створення інклюзивного туристського простору, інклюзивної інфраструктури, спорудження об'єктів нерухомості відповідно до норм та стандартів інклюзивності; інвалідністю;

- доступність усіх видів транспорту для користування ним людьми 3

- забезпечення якісних послуг щодо супроводження туристів шляхом навчання персоналу відповідним кваліфікаціям;

- інклюзивність культурно-розважальних об'єктів;

- інклюзивна складова маркетингової діяльності, зокрема формування комфортних умов бронювання, презентації туристських пропозицій тощо.

Крім того, стаття 30 Конвенції ООН про права інвалідів говорить про те, що люди з інвалідністю мають право брати участь нарівні з іншими в культурному житті, проведенні дозвілля і відпочинку. У пункті 5 цієї статті говориться, що «щоб надати інвалідам можливість брати участь нарівні 3 іншими у проведенні дозвілля та відпочинку й у спортивних заходах, держави-учасниці вживають належних заходів ... для забезпечення того, щоб інваліди мали доступ до спортивних, рекреаційних і туристичних об'єктів», а також «для забезпечення того, щоб інваліди мали доступ до послуг тих, хто займається організацією дозвілля, туризму, відпочинку та спортивних заходів» [7].

Вважаємо, що доступність передбачає адаптацію інфраструктурного середовища, а інклюзія в туризмі включає зміну відносин між людьми, які мають діяти спільно та комфортно перебувати в спільному туристичному просторі. Зважаючи на зазначене, доцільно створити таке середовище, яке об'єднувало б у собі процеси доступності та інклюзії, дозволило б людям з особливими потребами та людям без них рівноправно користуватися туристичною інфраструктурою.

В науковій літературі найчастіше можна зустріти поняття «доступне середовище». Так, доступне середовище - це така організація навколишнього простору, при якій будь-яка людина, незалежно від свого стану, фізичних можливостей і інших обмежень, має можливість безперешкодного доступу до будь-яких об'єктів соціальної, громадської, транспортної та іншої інфраструктури, а також може вільно пересуватися по будь-якому обраному туристичному маршруті [1].

На нашу думку, доступне середовище інклюзивного туризму - це вид безбар'єрного середовища, яке адаптоване у відповідності до вимог людей 3 особливими потребами, де усі без винятку туристи мають рівноправний, 
безперешкодний доступ до усіх туристичних об'єктів (безперешкодне пересування, відчуття комфорту, можливість вільно спілкуватися, знаходити необхідну туристичну інформацію тощо).

Виділимо основні компоненти доступного середовища інклюзивного туризму.

- інституційний, тобто удосконалення інституційного середовища розвитку інклюзії, формування стратегії та планів щодо забезпечення інклюзивності; трансформація відповідних органів влади та структур, що відповідають за інклюзивні процеси в регіонах країни.

- просторовий, тобто створення доступного середовища та безбар'єрної туристичної інфраструктури, що включає можливість пересування i користування спеціальними технічними пристроями для того, щоб люди з особливими потребами мали доступ до туристичної інфраструктури.

- інформаційний, тобто надання людям 3 особливими потребами повної інформації про діяльність туристичних об’єктів в доступних форматах i 3 використанням інформаційно-коммунікаціонних технологій, які враховують різні форми порушень (інвалідності).

- комунікативно-організаційний, тобто організація комунікації між усіма суб'єктами туристичної діяльності, в тому числі людьми з особливими потребами на засадах рівних можливостей, поваги та гідного відношення один до одного.

Формування доступного середовища вимагає розробку відповідних інклюзивних програм і заходів, призначених як для людей з особливими потребами так і людей без них.

Висновки. За результатами проведеного дослідження можна зробити висновок, що внутрішній туризм потребує формування доступного середовища. Під інклюзивним туризмом пропонуємо розуміти специфічний (безпечний) вид туризму, основною метою якого $є$ безбар'єрний доступ до усіх туристичних ресурсів, позитивний психологічний клімат, рівність можливостей усіх туристів, повномасштабне інформування людей 3 особливими потребами про можливості того чи іншого туристичного об'єкту, а також передбачає швидку здатність суб'єктів туризму перелаштовуватись відповідно до запитів людей з особливими потребами.

Запропоновані на основі здійсненого аналізу, шляхи формування доступного середовища інклюзивного туризму сприятимуть розвитку туристичної галузі, збільшенню обсягів реалізації української туристичної продукції на внутрішньому і зовнішньому ринках, виходу більшості туристичних підприємств на нові ринки збуту, а також дозволять усім без винятку туристам, в тому числі туристам з особливими потребами, отримувати більш якісні туристичні послуги.

\section{Список бібліографічного опису:}

1. Аникеева О. А., Анисимова Ю. А. Россия без барьеров: туризм, доступный для всех. Сервис в России и за рубежом. 2011. T. 25. № 6. С. 17-21.

2. Державна служба статистики України [Електронний ресурс]. Режим доступу: http://www.ukrstat.gov.ua

3. Закон України «Про Туризм» [Електронний ресурс]. Режим доступу: http://zakon0.rada.gov.ua/laws/show/324/95-

4. Інклюзивний вимір розвитку міст - центрів ділової активності України:тенденції та перспективи: наукова доповідь / НАН України. ДУ «Інститут регіональних досліджень імені М. І. Долішнього НАН України»; наук. Редактор М.І. Мельник. Львів, 2019. 55 с.

5. Інклюзивний туризм як вид реабілітації: наукове обгрунтування та перші кроки втілення у життя. Лепський В., Науменко Л., Борисова І.та ін. Український вісник медико-соціальної експертизи. 2016. № 4. С. 47- 52

6. Ковальська Л. В. Зарубіжний досвід розвитку туризму для неповносправних, та його інтерпретація в Україні. Матеріали III Всеукраїнської науково-практичної конференції «Стан та перспективи розвитку культурологічної науки в Україні»: Збірник тез доповідей (І частина). Миколаїв: Миколаївська філія КНУКіМ, 2017. 194 с.

7. Конвенция ООН о правах инвалидов [Електронний ресурс]. Режим доступу: http://www.un.org/ru/documents/decl_conv/ 8. Маншина Н.I. Основні пріоритети та причини вибору здравниць. Зб. 2-го Європейського конгресу з охорони здоров'я, 2009 р. Угорщина. С. 76.

9. Офіційний сайт Всесвітньої туристичної організації. [Електронний ресурс]. Режим доступу: http://www2.unwto.org/ 10. Офіційний сайт міжнародної організації ETAN. [Електронний ресурc]. Режим доступу: http://www.etan.org/ 
11. Офіційний веб-сайт Міністерства економічного розвитку і торгівлі України. [Електронний ресурс]. Режим доступу: http://www.me.gov.ua

12. Перфільєва М. В., Кирпич І.О. Правове забезпечення розвитку інклюзивного туризму в Україні. Молодий вчений. 2017. Вип. 4(44). С. 418-420.

13. Смирнова Д.Б., Смородина Ю.С. Безбарьерный туризм: основные понятия, перспективы развития. Мировая экономика, финансы и инвестиции: сб. матер. II Междунар. науч.-практ. конфер. 2013. [Електронний ресурс]. Режим доступу http://www.asconf.com/view_arhiv.

14. Угодникова О. І. Перспективи реалізації державної політики у розвитку інклюзивного туризму. Аспекти публічного управління. 2019. Т. 7 № 1-2. С. 37-42.

15. Хрущ Ю. М., Іванова В.М., Медведський Р.С. Туризм для інвалідів : сучасні підходи до визначення. Науковий вісник Херсонського державного університету. Серія: Географічні науки. Херсон, 2017. № 6. С. 206-211.

\section{References}

1.Anykeeva O.A., Anysymova Yu.A (2011), Rossyya bez barerov: turyzm, dostupnuj dlya vsex [Servys v Rossyy y za rubezhom]. p. 17-21. [in Russian].

2.Derzhavna sluzhba statystyky Ukrayiny [Electronic resource]. Access mode: http://www.ukrstat.gov.ua

3.Zakon Ukrayiny «Pro Turyzm» [Electronic resource]. Access mode: http://zakon0.rada.gov.ua/laws/show/324/95-

4.Inklyuzyvnyj vymir rozvytku mist - centriv dilovoyi aktyvnosti Ukrayiny:tendenciyi ta perspektyvy: naukova dopovid (2019).

NAN Ukrayiny. DU «Instytut regionalnyx doslidzhen imeni M.I. Dolishnogo NAN Ukrayiny»; nauk. Redaktor M.I. Melnyk. Lviv. p. 55. [in Ukrainian].

5.Inklyuzyvnyj turyzm yak vyd reabilitaciyi: naukove obgruntuvannya ta pershi kroky vtilennya u zhyttya (2016). Lepskyj V., Naumenko L., Borysova I. ta in. // Ukrayinskyj visnyk medyko-socialnoyi ekspertyzy. p. 47-52. [in Ukrainian].

6.Kovalska L.V. (2017), Zarubizhnyj dosvid rozvytku turyzmu dlya nepovnospravnyx, ta jogo interpretaciya v Ukrayini. Materialy III Vseukrayinskoyi naukovo-praktychnoyi konferenciyi «Ctan ta perspektyvy rozvytku kulturologichnoyi nauky v Ukrayini»: Zbirnyk tez dopovidej (I chastyna). Mykolayiv: VP «Mykolayivska filiya KNUKiM».p. 194. [in Ukrainian].

7.Konvencyya OON o pravax ynvalydov [Electronic resource]. Access mode: http://www.un.org/ru/documents/decl_conv/

8. Manshyna N.I. (2009), Osnovni priorytety ta prychyny vyboru zdravnycz [Zb. 2-go Yevropejskogo kongresu z oxorony zdorovya], Ugorshhyna. p. 76. [in Ukrainian].

9. Oficijnyj sajt Vsesvitnoyi turystychnoyi organizaciyi [Electronic resource]. Access mode: http://www2.unwto.org/

10. Oficijnyj sajt mizhnarodnoyi organizaciyi ETAN. [Electronic resource]. Access mode: http://www.etan.org/

11. Oficijnyj veb-sajt Ministerstva ekonomichnogo rozvytku i torgivli Ukrayiny [Electronic resource]. Access mode: http://www.me.gov.ua.

12. Perfilyeva M. V., Kyrpych I. O. (2017), Pravove zabezpechennya rozvytku inklyuzyvnogo turyzmu v Ukrayini [Molodyj vchenyj] p. 418-420. [in Ukrainian].

13. Smyrnova D.B., Smorodyna Yu.S. (2013), Bezbarernuj turyzm: osnovnble ponyatyya, perspektyvy razvytyya [Myrovaya эkonomyka, fynansruy ynvestycyy]: sb. mater. II Mezhdunar. nauch.-prakt. konfer.

14. Ugodnikova O. I. (2019), Perspektyvy realizaciyi derzhavnoyi polityky u rozvytku inklyuzyvnogo turyzmu [Aspekty publichnogo upravlinnya]. p. 37-42. [in Ukrainian].

15. Xrushh Yu. M., Ivanova V. M., Medvedskyj R. S. (2017), Turyzm dlya invalidiv : suchasni pidxody do vyznachennya ponyattya [Naukovyj visnyk Xersonskogo derzhavnogo universytetu] Seriya: Geografichni nauky. Xerson, p. 206-211. [in Ukrainian].

Дата подання публікації 20.03.2020 р. 